\title{
Vol. 552: 211-222, 2016 \\ Effects of climate on the mole crab Emerita brasiliensis on a dissipative beach in Uruguay
}

\author{
Eleonora Celentano ${ }^{1}$, Omar Defeo ${ }^{1,2, *}$ \\ ${ }^{1}$ UNDECIMAR, Facultad de Ciencias, Iguá 4225, 11400 Montevideo, Uruguay \\ ${ }^{2}$ GEPEIA, Centro Universitario Regional Este, Ruta Nacional No. 9 intersección con Ruta No. 15, Rocha, Uruguay
}

\begin{abstract}
Climate change is expected to have considerable impacts on sandy beach ecosystems through the loss of intertidal area and changes in physical properties. These changes may affect demography and life history traits of macrofaunal species. We evaluated the role of climate in explaining variations in population traits of the mole crab Emerita brasiliensis over $20 \mathrm{yr}$ on a sandy beach in Uruguay, based on a set of predictive hypotheses recently developed from studies of beach and climate-change ecology. Population abundance increased with sea surface temperature (SST), reproductive and recruitment periods were more extended, and recruitment was higher during warm years, when population structure showed a multi-modal structure. Decreasing asymptotic sizes and increasing growth rates were also observed concurrently with increasing SST. La Niña events, which in coastal Uruguayan waters are characterized by a higher influence of tropical oceanic waters (warm and salty), had marked positive impacts on abundance and individual growth. In a climate change scenario, an increasing frequency of extreme La Niña events is expected and therefore our results have strong implications. In a space-for-time substitution context, our long-term trends are reinforced by macroscale results that reported an increase in growth rates and in reproduction and recruitment periods, together with a decrease in female individual sizes, from temperate to tropical beaches of the Atlantic coast of South America. Spacefor-time substitution is highlighted as an alternative approach to analyze potential population changes resulting from climate change in these data-poor ecosystems.
\end{abstract}

KEY WORDS: Population traits $\cdot$ Long term study $\cdot$ Climate change $\cdot$ Sea surface temperature La Niña $\cdot$ Space-for-time substitution

\section{INTRODUCTION}

Sandy beaches dominate open coasts worldwide, and their position between the sea and land make them highly vulnerable to climate change (Schoeman et al. 2014). These ecosystems are at risk of significant habitat loss and ecological impacts, acidification and erosion caused by sea level rise, as well as more frequent storms induced by warmer air and sea surface temperatures (SST) (Dugan et al. 2010, IPCC 2014). Increasing SST, storminess, and velocity, periodicity, and frequency of onshore winds have significantly altered the physical properties of sandy beaches (Ortega et al. 2013). Indeed, increased water

\footnotetext{
${ }^{*}$ Corresponding author: odefeo@dinara.gub.uy
}

depth caused by higher tidal velocity (Pethick 1993) has led to a shift in sediment composition towards coarser particles and an increase in the steepness of beach profiles and in wave exposure (Goss-Custard et al. 1990, Ortega et al. 2013). These climate change issues are also expected to have considerable impacts on sandy beach macrofauna through the loss of intertidal area (Schoeman et al. 2014), impacting ecosystem functioning and species richness and abundance (Yamanaka et al. 2010). A narrow (i.e. meters) intertidal fringe defines a restricted habitat with absence of spatial refuges for resident benthic fauna with a very limited dispersal capacity. This is of utmost importance, considering that macrofaunal

() The authors 2016. Open Access under Creative Commons by Attribution Licence. Use, distribution and reproduction are unrestricted. Authors and original publication must be credited. 
species richness is positively correlated with the extent of the intertidal area (McLachlan \& Dorvlo 2005, Defeo \& McLachlan 2013). In particular, dissipative beaches, which are defined by fine sands, gentle slopes, low substrate penetrability and high water content, host the greatest biodiversity among all beach types (Defeo \& McLachlan 2013, Barboza \& Defeo 2015). These systems are at major risk due to their erosive nature and the much greater run-up and backwash of waves on gentle slopes (Defeo et al. 2009, Ortega et al. 2013).

Ecological responses of intertidal macrofauna to climate variability encompass factors such as changes in the timing of reproduction, population dynamics, abundance, spatial distribution, and interspecific interactions (Sagarin et al. 1999, Riascos 2006, Riascos et al. 2009, Revell et al. 2011, Ortega et al. 2012). Hence, time series of biological and physical variables are crucial to understand how sandy beach macrofauna and its habitat respond to changes in climatic conditions (Brown et al. 2011, Bessa et al. 2014). Few long-term studies have assessed the effects of climate change on sandy beach macrofauna (Revell et al. 2011, Ortega et al. 2012, Defeo et al. 2013), and therefore many of the predictions of the likely impacts on these species are derived from other systems (Defeo et al. 2009, Dugan et al. 2010). This paucity of sandy beach studies related to global warming is partially due to the lack of multiyear, large-scale data sets which assess the effects of critical stressors on patterns and processes. In this context, the space-for-time substitution modeling approach could be a useful alternative to infer temporal trends from spatial variations in population features and ecological processes across sites that vary in environmental conditions (Pickett 1989, Fukami \& Wardle 2005, Blois et al. 2013, Lester et al. 2014).

In South America, intertidal suspension feeders of the genera Donax, Emerita, and Mesodesma dominate the biomass of invertebrate assemblages in dissipative sandy beaches (Defeo \& de Alava 1995, Defeo 2003). Among them, the cold-water species of the genus Mesodesma have been particularly affected by climate change and concurrent changes in physical conditions of the habitat, both in the Atlantic (Ortega et al. 2012, 2016, Defeo et al. 2013) and the Pacific (Arntz et al. 1987, Riascos et al. 2009). An increase in SST over the past 3 decades along the Atlantic coast has drastically affected the abundance and individual size of the yellow clam M. mactroides (Ortega et al. 2012, 2016). Other indirect and unpredictable effects on this species included changes in phytoplankton composition and abundance (Odebrecht et al. 2014), which markedly diminished its food availability (Bergamino et al. 2011). While these results are restricted to a few species, they nevertheless indicate a direct link between regional climate change and changes in population structure and abundance.

The genus Emerita (Crustacea: Anomura: Hippidae) constitutes one of the most conspicuous components of sandy beach ecosystems. These suspension feeders are well-adapted to live in the intertidal of exposed, high-energy sandy beaches around the world (Dugan et al. 1994, Subramoniam \& Gunamalai 2003). On the Atlantic coast of South America, the mole crab E. brasiliensis is commonly found on reflective and dissipative sandy beaches from Venezuela to Uruguay. This species has shown clear latitudinal gradients in life history traits, population dynamics, and demographic features from tropical to temperate beaches, including (Defeo \& Cardoso 2002, 2004) (1) an exponential decrease in abundance and natural mortality and an increase in body size and life span; (2) a shift from continuous to seasonal reproduction and recruitment; and (3) a sex ratio strongly biased towards females, which have significantly lower growth and mortality rates. These large-scale patterns follow variations in SST and could be attributed to an extreme sensitivity of the species to environmental variations and to its biogeographic affinity to the tropics (Defeo \& Cardoso 2004). Moreover, E. brasiliensis is particularly abundant on dissipative beaches (Celentano \& Defeo 2006), which constitute the main source habitats in a metapopulation context (Celentano et al. 2010).

We assessed long-term trends in E. brasiliensis on a dissipative sandy beach in Uruguay. We evaluated the role of climate in explaining variations in mole crab abundance, population structure, and individual growth over a $20 \mathrm{yr}$ period. To this end, we combined theory from beach ecology and climate-change ecology to evaluate a set of predictive hypotheses recently developed by Schoeman et al. (2014) regarding climate impacts on beaches. Taking into account the systematic increase in SST observed in recent decades in the region (Ortega et al. 2016) and the fact that $E$. brasiliensis is a species with tropical affinities, we predict that the mole crab on a dissipative beach in Uruguay experienced a long-term (1) increase in population abundance and in the number of size classes represented; (2) extension of its reproduction and recruitment seasons; and (3) increase in individual growth rates and decrease in individual sizes. In a space-for-time substitution context, if these predictions hold, long-term patterns in mole crab life history traits will follow the latitudinal patterns detailed above. 


\section{MATERIALS AND METHODS}

The study was conducted at Barra del Chuy, a dissipative microtidal (tidal range $=0.5 \mathrm{~m}$ ) oceanic sandy beach in Uruguay $\left(33^{\circ} 84^{\prime} \mathrm{S}, 53^{\circ} 27^{\prime} \mathrm{W}\right)$, with a wide surf zone, fine to very fine well-sorted sands, as well as exposure to strong wave action and a gentle slope, both of which make this beach particularly vulnerable to sea level rise (Ortega et al. 2013). The beach was sampled mostly on a monthly or seasonal (at least 4 times a year) basis from March 1988 to March 2010 (year 1992 was not sampled). Three transects spaced $8 \mathrm{~m}$ apart were made perpendicular to the shoreline, with sampling units (SUs) starting at the base of the dunes and continuing seaward at $4 \mathrm{~m}$ intervals, until 2 consecutive SUs yielded no mole crabs (Celentano \& Defeo 2006). In each SU, a sheet metal cylinder $27 \mathrm{~cm}$ in diameter was used to remove the sediment up to a depth of $40 \mathrm{~cm}$. Mole crabs retained after sieving through a $0.5 \mathrm{~mm}$ mesh were fixed and, in the laboratory, measured to the nearest $0.01 \mathrm{~mm}$ from the tip of the rostrum to the distal scoop of the cephalothorax (carapace length: CL). Mole crabs were classified as megalopae (nonadults) or adults. Megalopae were those with an undeveloped ocular peduncle and with plumose pleopods (Veloso \& Cardoso 1999). Adults were sorted into males with and without spermatophores, females without eggs, and ovigerous females.

Species abundance (total and by population component: megalopae and adults) was estimated by the number per strip transect (ind. $\mathrm{m}^{-1}$ ) following Defeo (1996). Reproductive and recruitment periods were inferred from the months with occurrence of reproductive (ovigerous females and males with spermatophores) and recruitment (megalopae) components in the total number of sampling events performed in 5 periods with monthly sampling periodicity (1988-1989, 1996-1997，1999-2001，2002-2004, 2008-2010).

To assess long-term changes in population structure, an index of recurrence of size classes (IRSC, Celentano et al. 2010) was estimated as follows:

$$
\operatorname{IRSC}=\frac{N_{L}}{N T_{L}}
$$

where $N_{L}$ defines the number of size classes $\left(L_{i}\right.$ grouped in $1 \mathrm{~mm}$ bins) in a given month, and $N T_{L}$ is the total number of size classes observed for the species throughout the study period. The IRSC is derived from the index of recurrence in recruitment (Caddy \& Defeo 2003) and ranges between 0 and 1 (all size classes present). IRSC values close to 1 suggest periodic recruitment patterns, whereas values approaching 0 suggest irregular/spasmodic recruitment.

Individual growth patterns of female mole crabs were determined by analyzing monthly length-frequency distributions (LFDs) in those time intervals with high sampling frequency $(1988-1989,1996-$ 1997, 1999-2001, 2002-2004, and 2008-2010). We followed the procedure detailed by Gómez \& Defeo (1999), summarized as follows: (1) for each month, we separated normally distributed components of size frequencies by maximum likelihood, through the application of the routine NORMSEP (Gayanilo \& Pauly 1997); (2) as we followed each cohort through its entire life span, we were able to assign absolute ages to relative ones (lengths) and thus to build an age-length key. Time 0 (month of birth) was defined on the basis of the size at recruitment of a mole crab to the beach (CL close to $2 \mathrm{~mm}$ ). Subsequent ages were assigned from time 0 , taking into account the date of the $i^{\text {th }}$ sample, measured as a portion of the year; (3) the age-length key obtained in (2) was used to fit the generalized von Bertalanffy growth function (VBGF, Eq. 2) that allows for the estimation of growth seasonality as follows (Gayanilo \& Pauly 1997):

$$
L_{t}=L_{\infty}\left[1-\mathrm{e}^{-K\left(t-t_{0}\right)+\left(\frac{K C}{2 \pi}\right) \sin 2 \pi\left(t-t_{s}\right)-\left(\frac{K C}{2 \pi}\right) \sin 2 \pi\left(t_{0}-t_{s}\right)}\right]
$$

where $L_{t}$ is the length at time $t_{1} L_{\infty}$ is the asymptotic length, $K$ is the curvature parameter that measures the rate at which the organisms reach the asymptotic length, $t_{0}$ is the theoretical length at age $0, C$ is the amplitude of the seasonal growth oscillation, and $t_{s}$ -0.05 is the winter point $(W P)$, defined as the time of year in which growth is minimal or stopped and is expressed as a decimal fraction of the year. A quasiNewton method was used to estimate the parameters (mean $\pm \mathrm{SE}$ ). Growth curves of mole crabs were compared by likelihood ratio tests, under different null hypotheses (Kimura 1980, Cerrato 1990). First, we simultaneously compared the 3 main parameters of the VBGF $\left(L_{\infty}, K\right.$, and $\left.t_{0}\right)$ from the 5 specific time periods considered under the general null hypothesis to be constant through time $(C$ was assumed constant in all analyses). Following this, the model selection process was performed by sequentially altering the number of parameters under comparison (Haddon 2001). We also used the growth indices: $\phi^{\prime}(=2 \times \log$ $\left.L_{\infty}+\log K\right)$ to assess female growth performance (Pauly \& Munro 1984); and $\omega\left(=K \times L_{\infty}\right)$, defined as the instantaneous growth rate near to the point at which the mole crab length is 0 (Gallucci \& Quinn 1979). Growth parameters of male mole crabs were 


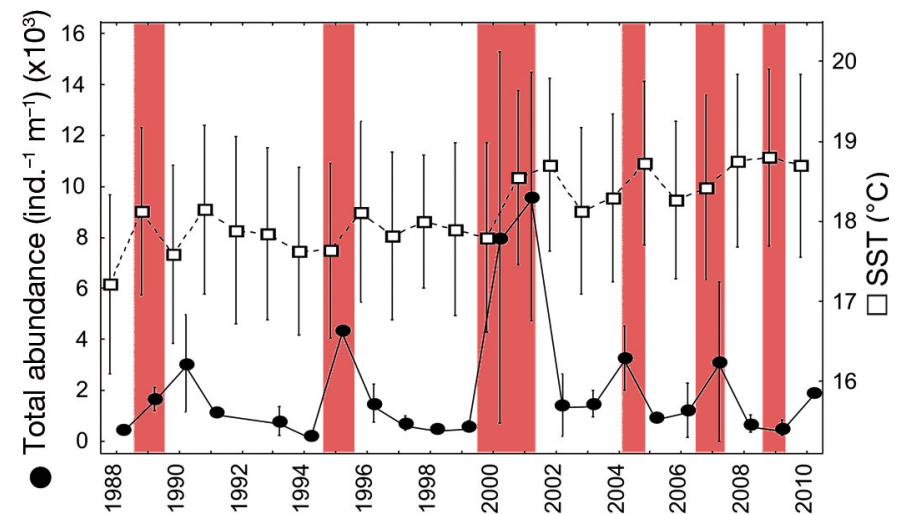

Fig. 1. Long-term fluctuations (mean $\pm \mathrm{SE}$ ) of total annual abundance (all population components pooled, black circles) of Emerita brasiliensis and sea surface temperature (SST, white squares) for the period 1988 to 2010 at Barra del Chuy beach, Uruguay. SST values are from Reynolds et al. (2002). Periods in which La Niña episodes were registered (Niedzielski 2014) are highlighted in red

not estimated due to their very low abundance, which precluded the progression of modes through time.

SST and the corresponding anomalies (SSTA) were calculated based on the data series in Reynolds et al. (2002) by averaging SSTA from $48^{\circ} \times 3^{\circ}$ grid cells of the shelf and the adjacent oceanic region in the Southwestern Atlantic Ocean (SAO). SSTA data for empirical orthogonal function analysis were obtained from the Extended Reconstructed Sea Surface Temperature, version 3 (ERSST_V3) dataset based on the International Research Institute/Lamont-Doherty Earth Observatory Climate Data Library (IRI/LDEO 2013). Previous exploratory multivariate studies relating mole crab features and environmental variables that could be relevant in a climate change context (e.g. wind speed, grain size, beach width, beach slope) showed that SST was the relevant explanatory variable for long-term trends (Celentano 2014), and therefore SST was used here for model fitting. Relationships between population descriptors (abundance, biomass, reproductive and recruitment periods, IRSC, and individual growth) and SST (extracted from Reynolds et al. 2002) were modeled by linear or nonlinear fitting. In all cases, the model that best explained the relationship between biological and physical variables was selected based on $\mathrm{R}^{2}$.

\section{RESULTS}

\section{First prediction: abundance and size class representation increase with SST}

Abundance of Emerita brasiliensis varied markedly through time (Fig. 1) and increased exponentially with SST (Fig. 2). Abundance was especially higher in the summers of the warmest years, which in most

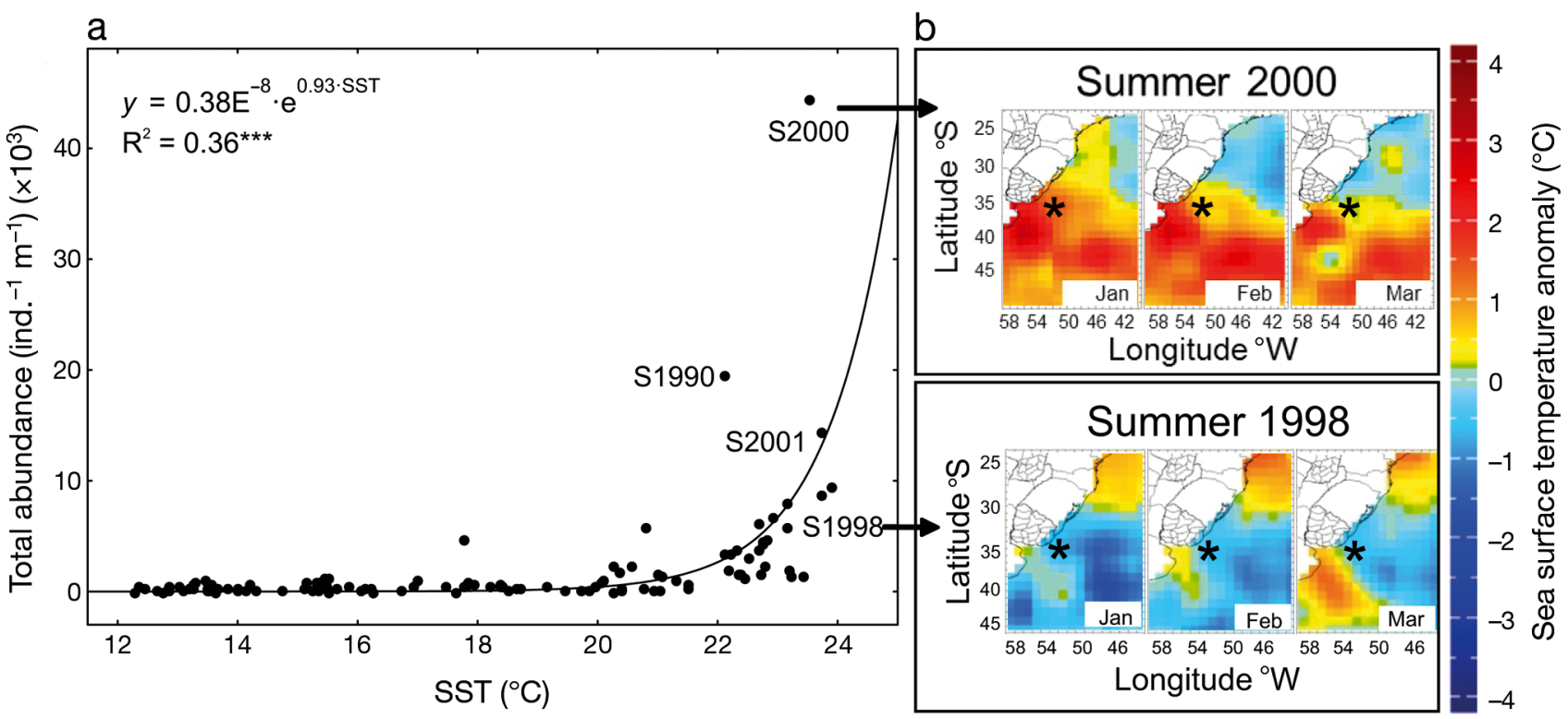

Fig. 2. (a) Exponential relationship between seasonal abundance of Emerita brasiliensis and sea surface temperature (SST) at Barra del Chuy beach, Uruguay, between 1988 and 2010. ${ }^{* * *} \mathrm{p}<0.001$. (b) Isotherm maps in the Uruguayan waters of the southwestern Atlantic Ocean (*) for a cold summer (1998) with low mole crab abundance and a warm one (2000) where the highest abundance was recorded. SST values are from Reynolds et al. (2002) 
cases coincided with La Niña episodes (Niedzielski 2014; our Fig. 1), defined by positive SST anomalies (Fig. 2). The lowest mole crab abundance was registered in the summer of 1998, the coldest summer recorded throughout the study period (Fig. 2).

Mole crab recruitment (estimated by megalopae abundance in the recruitment season) showed large fluctuations through time that were significantly related to changes in SST (Fig. 3a). Megalopae abundance peaked in 1990, 2000-2001，2004, and 2007 (Fig. 3b), which in most cases coincided with La Niña episodes (Fig. 1). The highest recruitment abundance was obtained in 2007, close to the end of the study period, concurrently with the highest SST value.

The relationship between abundance of adults $(A)$ and recruits $(R)$ was significantly explained by linear $\left(F_{1,17}=9.51 ; \mathrm{R}^{2}=0.36, \mathrm{p}<0.01\right)$ and exponential $\left(F_{2,17}=10.68 ; \mathrm{R}^{2}=0.33, \mathrm{p}<0.05\right)$ models. However, the best fit was obtained when SST was incorporated as a predictor of recruitment abundance in the exponential model of the form $\left(F_{2,17}=12.07 ; \mathrm{R}^{2}=0.38\right.$, $\mathrm{p}<0.001$ ):

$$
R=\mathrm{e}^{-b A+c \operatorname{SST}}
$$

where $b=2.89 \times 10^{-4}$ and $c=0.32$ were significant parameters ( $\mathrm{p}<0.001$ in both cases).

Concerning the population structure of the mole crab, higher E. brasiliensis recruitment in La Niña years promoted a wider representation of the full range size of classes, i.e. 2 to $26 \mathrm{~mm}$, which influenced the population structure in subsequent years (Fig. 4). Consequently, monthly IRSC values were significantly correlated with $\mathrm{SST}\left(\mathrm{R}^{2}=0.11, \mathrm{p}<0.05\right.$; Fig. 5).

\section{Second prediction: duration of reproductive and recruitment periods increases over time}

The reproductive season of the mole crab, inferred from the number of months with occurrence of breeding adults (ovigerous females and males with spermatophores), was concentrated between December and May in 1988-1989, representing $50 \%$ of the months sampled. In 2008-2010, breeding adults also occurred in November and July, accounting for $80 \%$ of the months sampled (Fig. 6).

The recruitment period of the mole crab, inferred from the occurrence of megalopae, increased over time from 1996 onwards. In 1996-1997, megalopae occurred in austral autumn months (i.e. May to June), whereas in 2008-2010, this population component also occurred in late spring and summer (from November onwards), indicating a more extended recruitment season in recent years (Fig. 6).

\section{Third prediction: growth increases with SST}

Growth curves of female mole crabs significantly explained 96 to $99 \%$ of the variance in the data, and most growth parameters of the VBGF were highly significant $(\mathrm{p}<0.001)$ for the 5 analyzed periods (Table 1, Fig. 7). Likelihood ratio tests indicated highly significant differences in mole crab growth between time periods. Of the 10 comparisons, 8 showed significant differences in the combination of growth parameters, and in 4 cases, the combination given by $K$ and $L_{\infty}$, which defines the growth index $\omega$, significantly differed among growth curves $(\mathrm{p}<$ 0.005 , Table 2). The observed long-term differences
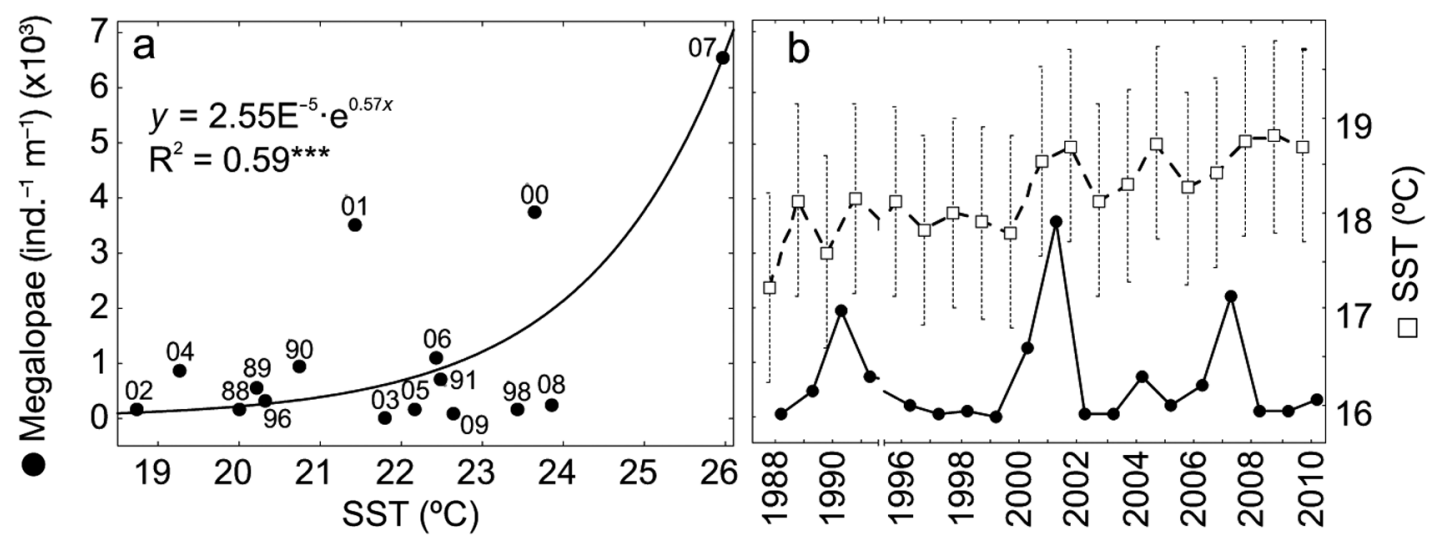

Fig. 3. (a) Relationship $\left({ }^{* * *} \mathrm{p}<0.001\right.$ ) between Emerita brasiliensis megalopae abundance (recruitment period) and sea surface temperature (SST). (b) Annual fluctuations (mean \pm SE) in megalopae abundance (black circles) and SST (white squares) at Barra del Chuy beach, Uruguay, between 1988 and 2010. SST values are from Reynolds et al. (2002) 


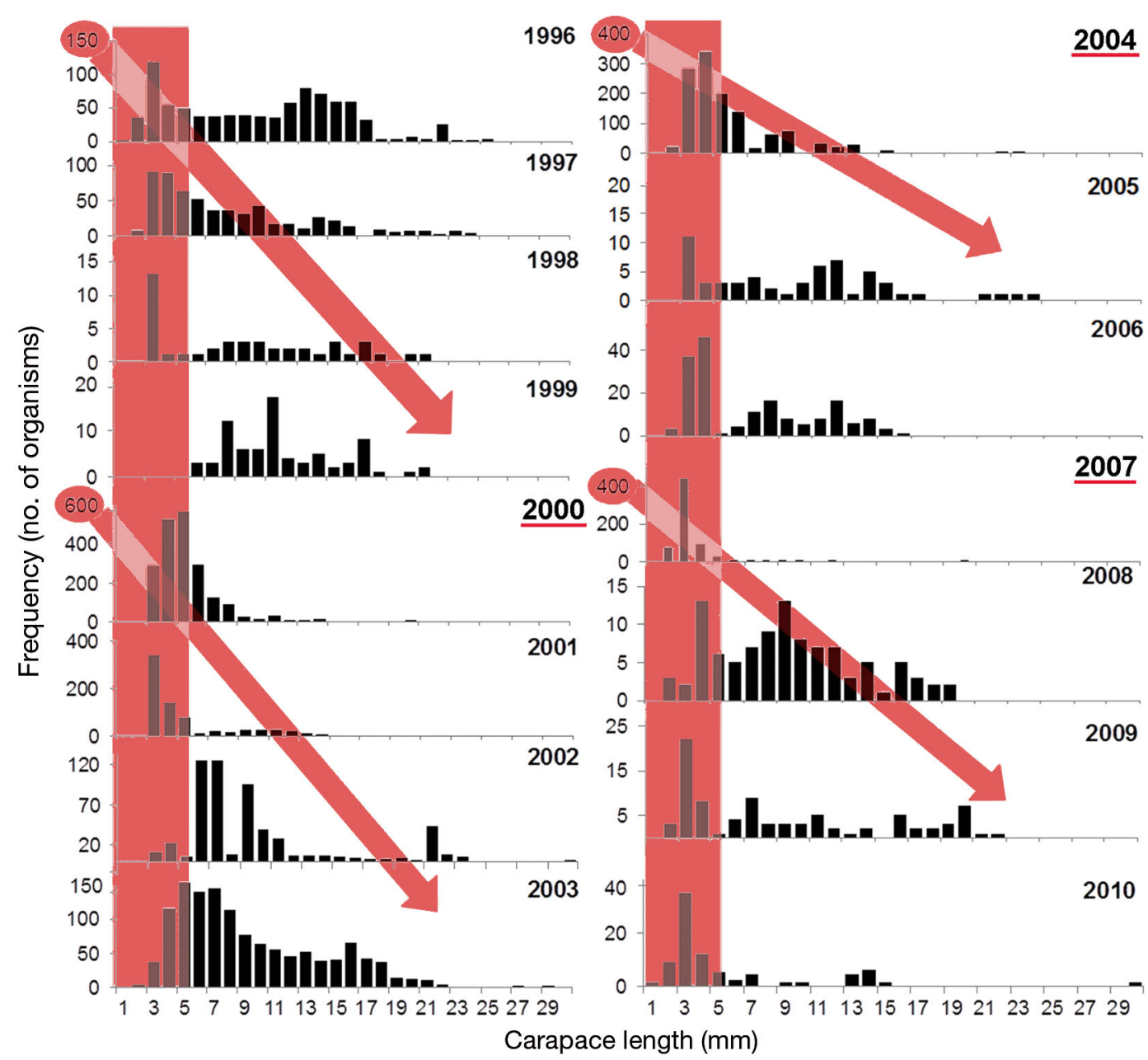

Fig. 4. Length-frequency distributions of Emerita brasiliensis (sexes pooled) for the period 1996 to 2010 at Barra del Chuy beach, Uruguay. Body size of megalopae (carapace length $<5 \mathrm{~mm}$ ) and high frequency during La Niña episodes (encircled) are highlighted, and their influence on the number of adults in subsequent years is indicated by red arrows. La Niña years promoted a wider representation of the full range size of classes, which influenced the population structure in subsequent years;

La Niña events occurred in the years 2000, 2004, and 2007 (underlined) and 1995 (no samples taken, thus not shown)

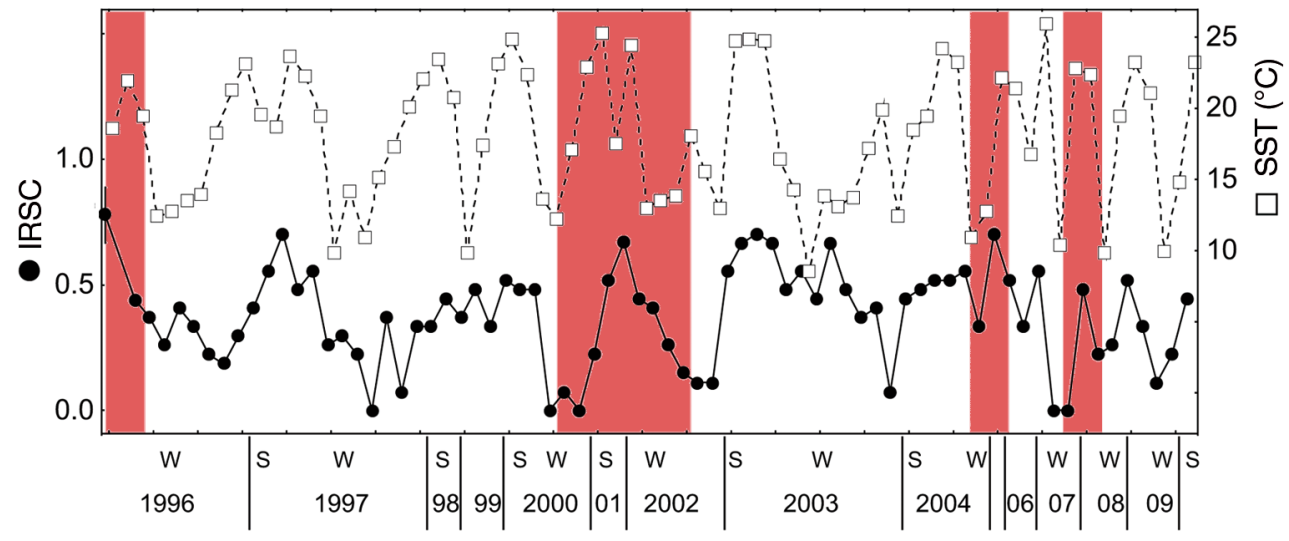

Fig. 5. Monthly variations in the index of recurrence of size classes (IRSC, black circles) of Emerita brasiliensis and sea surface temperature (SST, white squares), for the period 1996 to 2010 (S: summer; W: winter). Both variables were significantly corre lated $\left(R^{2}=0.11, p<0.05\right)$. SST values are from Reynolds et al. (2002). La Niña episodes are highlighted in red 

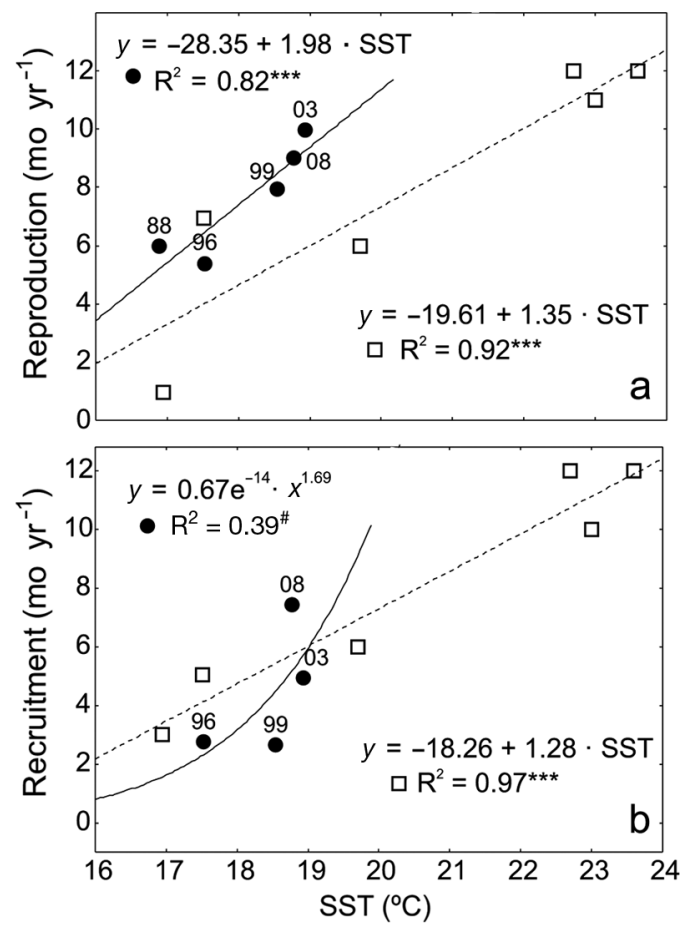

Fig. 6. Long-term relationships between sea surface temperature (SST; values are from Reynolds et al. 2002) and annual duration of (a) reproductive and (b) recruitment events of Emerita brasiliensis at Barra del Chuy beach, Uruguay (black circles). The first year of each analyzed period is indicated. Macroscale results reported by Defeo \& Cardoso (2002) are included for comparative purposes (white squares). ${ }^{* * *} \mathrm{p}<0.001 ;{ }^{\#} 0.05<\mathrm{p}<0.1$

in E. brasiliensis growth can therefore be attributed primarily to variations in growth rates $\left(\mathrm{mm} \mathrm{yr}^{-1}\right)$ instead of differences in individual growth parameters. Female mole crabs showed a reduction in $L_{\infty}$ and an increase in the curvature parameter $K$ with increasing SST (Fig. 8). Moreover, $\omega$ was almost 2 times higher at the end of the study period (2008-2010; $\omega=71.25)$, followed by the growth curve

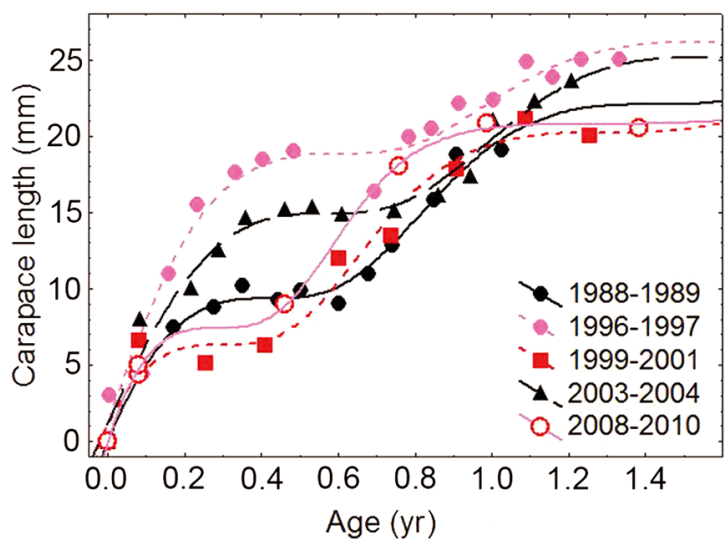

Fig. 7. von Bertalanffy growth curves for female mole crabs Emerita brasiliensis at Barra del Chuy beach, Uruguay, for 5 periods spanning 2 decades of data

fitted for 1999-2001 ( $\omega=43.43)$, with both cases coinciding with La Niña episodes (Table 1). The period 1996-1997, which immediately followed the La Niña episode of 1995, also showed high growth rates (Fig. 7), concurrently with a wide representation of size classes (see Fig. 4).

\section{DISCUSSION}

Our 20 yr population study of Emerita brasiliensis on a Uruguayan sandy beach showed that population abundance increased with SST, the reproductive and recruitment periods were more extended, and recruitment was particularly successful during warm years, when the mole crab population showed a multi-modal structure. Moreover, decreasing asymptotic sizes and increasing growth rates were observed concurrently with increasing SST. Thus, demographic and biological traits of the mole crab changed in ways consistent with expectations under

Table 1. Results of the von Bertalanffy growth models fitted by nonlinear least squares for female mole crabs Emerita brasiliensis at Barra del Chuy beach, Uruguay (in all cases, $\mathrm{p}<0.001)$. The parameter of growth oscillation was set constant $(C=1)$ for fitting. Mean $( \pm \mathrm{SE})$ estimates of the parameters defined in Eq. (2) are shown. $L_{\infty}$ : asymptotic length; $K$ : curvature parameter that measures the rate at which the organisms reach the asymptotic length; $t_{0}$ : theoretical length at age $0 ; W P$ : winter point.

The growth indices $\phi$ ' and $\omega$ are also included (see 'Materials and methods' for details)

\begin{tabular}{|lccccc|}
\hline Parameter & $1988-1989$ & $1996-1997$ & $1999-2001$ & $2003-2004$ & $2008-2010$ \\
\hline$L_{\infty}(\mathrm{mm})$ & $27.16(4.74)$ & $28.22(1.98)$ & $22.62(2.83)$ & $31.69(5.68)$ & $21.27(0.42)$ \\
$K\left(\mathrm{yr}^{-1}\right)$ & $1.25(0.38)$ & $1.52(0.31)$ & $1.92(0.66)$ & $0.94(0.32)$ & $3.35(0.29)$ \\
$t_{0}(\mathrm{yr})$ & $0.001(0.01)$ & $-0.01(0.02)$ & $-0.02(0.03)$ & $-0.02(0.02)$ & $0.001(0.004)$ \\
$W P$ & $0.42(0.02)$ & $0.39(0.04)$ & $0.29(0.04)$ & $0.43(0.03)$ & $0.28(0.01)$ \\
$\mathrm{R}^{2}$ & 0.98 & 0.96 & 0.96 & 0.97 & 0.99 \\
$\omega\left(\mathrm{mm} \mathrm{yr}^{-1}\right)$ & 33.95 & 42.89 & 43.43 & 29.79 & 71.25 \\
$\phi^{\prime}$ & 2.96 & 3.08 & 2.99 & 2.97 & 3.18 \\
\hline
\end{tabular}


Table 2. Results of the likelihood ratio tests comparing von Bertalanffy growth parameters in Emerita brasiliensis females at Barra del Chuy beach, Uruguay, under different null hypotheses. Significant parameters or combinations (experiment-wise Bonferroni significance level $=0.005$ ) are listed. ns: no significant differences between growth curves. See Table 1 for parameter definitions

\begin{tabular}{|c|c|c|c|c|}
\hline Time period & 1988-1989 & 1996-1997 & 1999-2001 & 2003-2004 \\
\hline 1996-1997 & $\begin{array}{c}L_{\infty} \\
K \\
t_{0} \\
L_{\infty} K \\
K t_{0}\end{array}$ & & & \\
\hline 1999-2001 & ns & $\begin{array}{c}L_{\infty} \\
K \\
t_{0} \\
L_{\infty} t_{0} \\
K t_{0}\end{array}$ & & \\
\hline 2003-2004 & $\begin{array}{c}L_{\infty} \\
K \\
t_{0} \\
L_{\infty} K \\
L_{\infty} t_{0} \\
K t_{0}\end{array}$ & $\begin{array}{c}L_{\infty} \\
K \\
t_{0} \\
L_{\infty} K \\
L_{\infty} t_{0}\end{array}$ & $\begin{array}{c}L_{\infty} \\
t_{0} \\
L_{\infty} K \\
L_{\infty} t_{0} \\
K t_{0}\end{array}$ & \\
\hline 2008-2010 & $\begin{array}{c}L_{\infty} \\
K \\
t_{0} \\
L_{\infty} t_{0} \\
K t_{0}\end{array}$ & $\begin{array}{c}L_{\infty} \\
K \\
t^{0} \\
L_{\infty}^{0} t_{0}\end{array}$ & $\begin{array}{c}L_{\infty} \\
K\end{array}$ & ns \\
\hline
\end{tabular}

SST was an important explanatory variable in mole crab abundance throughout the $20 \mathrm{yr}$ analyzed. Total abundance increased exponentially with SST, particularly in years when La Niña events occurred. This trend driven by SST was also meaningful to explain long-term recruitment patterns. Even though SST could not be singled out as the only variable driving the patterns, it could be considered as an aggregate variable that has various simultaneous effects on the nearshore beach environment and in the resident fauna (Ortega et al. 2013, 2016). Diaz et al. (1998) also found a strong correlation between the SSTA associated with El Niño-Southern Oscillation events in the SAO and precipitation anomalies for Uruguay. In particular, strong La Niña events that occurred in 1988-1989 and 1999-2000 (Baethgen \& Giménez 2001, Grimm 2011) led to low precipitation and a higher incidence of the Brazil Current, which is associated with warm and salty tropical water in the area (SST $>20^{\circ} \mathrm{C}$ and salinity > 36: Ortega \& Martínez 2007). Thus, our results reinforce the notion that species with complex life cycles and high fertility like E. brasiliensis are extremely labile to environmental fluctuations. Furthermore, climate change, the latter reflected in the monotonic and systematic long-term increase in SST observed in the SAO in recent decades (Ortega et al. 2012, 2013).

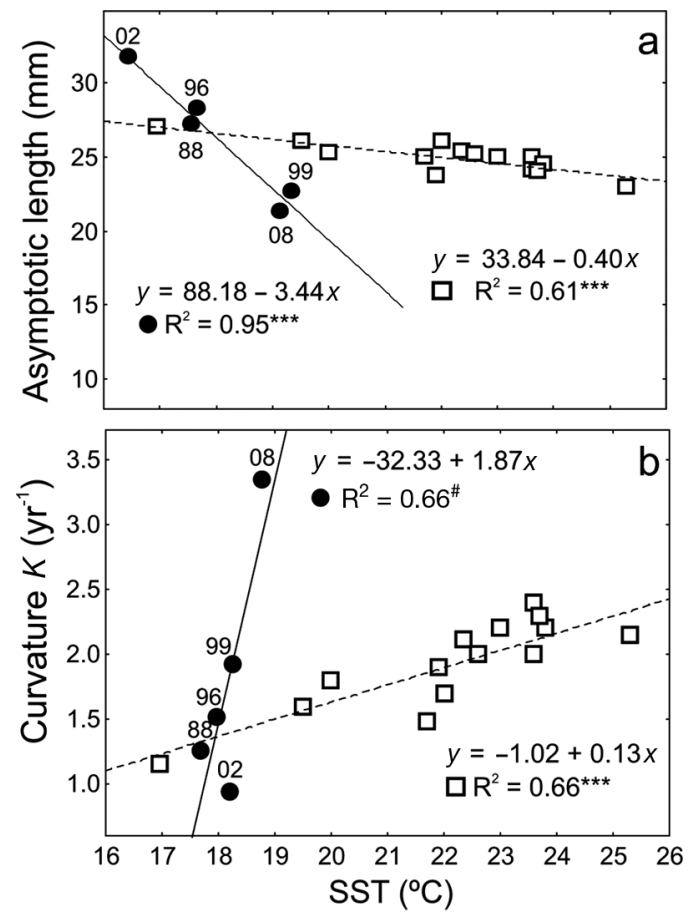
the long-term correlation found here between mole crab population traits and SST highlights the importance that favorable years (not captured in a shortterm study) can have for the dynamics of marginal populations (Sexton et al. 2009), especially in a context of climate variability. In this vein, the Uruguayan coast constitutes the leading (southernmost or poleward) edge of the E. brasiliensis distribution, and the trends reported here are in agreement with responses of various species to recent climate change, particularly at their poleward distributions (e.g. Parmesan \& Yohe 2003, Chen et al. 2011). Our results also reinforce the notion that climate change effects are expected to be strongest at the edges of species' ranges (Poloczanska et al. 2013).

The effect of climate change elicits opposite responses in species with different biogeographic

Fig. 8. Relationships between sea surface temperature (SST) of the swash zone and von Bertalanffy growth parameters for female Emerita brasiliensis in Barra del Chuy beach, Uruguay (black circles): (a) asymptotic length $L_{\infty}$ and (b) curvature parameter $K$. The first year of each analyzed reported by Defeo \& Cardoso (2002) and Veloso \& Cardoso (1999) are included for comparative purposes. ${ }^{* * *} \mathrm{p}<0.001$ and ${ }^{\#} 0.05<\mathrm{p}<0.10$ period is indicated. Macroscale results (white squares) 
origins, defined as diagnostic fingerprints (Parmesan \& Yohe 2003, Poloczanska et al. 2013). At Barra del Chuy, abundance and individual size of the yellow clam Mesodesma mactroides, a cold-water species that integrates the intertidal guild of suspension feeders with $E$. brasiliensis on sandy beaches of the $\mathrm{SAO}$, has drastically decreased in the last $30 \mathrm{yr}$ (Ortega et al. 2012, 2016). Indeed, mass mortalities have decimated yellow clam populations throughout the species' distribution range (Brazil, Uruguay, and Argentina), mostly during austral summers (Odebrecht et al. 1995, Fiori et al. 2004), after a shift from a cold to a warm phase during the 1990s (Ortega et al. 2012, 2016). The drastic and opposite changes observed in cold and warm water sandy beach species in the course of long-term observations suggest that regional warming could have triggered changes in the structure of the guild of suspension feeders at Barra del Chuy beach, reducing the $M$. mactroides population and enhancing populations of $E$. brasiliensis and the sympatric wedge clam Donax hanleyanus, which have tropical affinities and are subordinate competitors for space and food (Defeo \& de Alava 1995, Defeo 2003, Schoeman et al. 2014). This supports the perception that climate change, through the direct effects of temperature on survival, can affect the abundance and distribution of species, thus changing the competitive balance in closely related populations (Ottersen et al. 2001, Poloczanska et al. 2008, 2014).

The observed increase in the extent of reproductive and recruitment periods of $E$. brasiliensis supports our predictions and indicates a positive response of species with tropical affinities to increasing temperatures at the cold edge of their range. Warming has advanced and extended the occurrence of population processes in E. brasiliensis, notably the breeding and recruitment seasons, and these long-term trends agree with phenological responses to global warming (Parmesan 2007, Chambers et al. 2013, Schwartz 2013). In a space-for-time substitution context, our results were consistent with macroscale (2700 $\mathrm{km}$ of the species distribution) findings that reported continuous reproduction in tropical and subtropical mole crab populations and marked seasonality in temperate populations (Fig. 6), thus following latitudinal variations in water temperature (Defeo \& Cardoso 2002, 2004).

LFDs and IRSC estimated for $E$. brasiliensis gave additional support to the first prediction about population structure and abundance. In La Niña years and those immediately following La Niña episodes, high recruitment abundance and a full representation of individual sizes were observed (Figs. 4 \& 5). Riascos (2006) also reported positive effects of La Niña on growth and reproduction of another conspicuous filter feeder with tropical affinities, the bivalve $D$. dentifer, which inhabits South American Pacific sandy beaches. These trends were attributed to higher food availability during La Niña episodes. Body size is a major determinant of life histories, demography, nutrient turnover rate, and food-web structure (Edeline et al. 2013), and decreasing body size has been observed as a universal response to increasing temperatures (Angilletta 2009, Gardner et al. 2011). In this sense, mole crab asymptotic length $\left(L_{\infty}\right)$ linearly decreased with SST (Fig. 8), concurrently with higher growth rates. Therefore, current warming can potentially disrupt ecosystem function and services by altering body sizes through the magnification of competitive asymmetry in favor of smaller organisms (Edeline et al. 2013). Under a climate change scenario, expected warming and consequent body downsizing should drive the architecture of temperate food webs towards structures more consistent with the tropics (Edeline et al. 2013). These issues are in agreement with the observed changes in the sandy beach ecosystem analyzed here, where body downsizing was observed for the guild of intertidal suspension feeders $M$. mactroides, E. brasiliensis, and the wedge clam D. hanleyanus (Ortega et al. 2012, 2016, present study).

The space-for-time substitution approach also holds when looking at the relationship between SST and individual growth of the mole crab population. Indeed, a decrease in the asymptotic length $\left(L_{\infty}\right)$ and an increase in the curvature parameter $K$ with increasing SST were detected across a period of warming (Fig. 8). This is consistent with the significant correlation found between female growth parameters and SST (inverse with $L_{\infty}$ and direct with $K)$ at a macroscale, along the Atlantic coast of South America (Defeo \& Cardoso 2002, 2004) (Fig. 8). Moreover, Veloso \& Cardoso (1999) found increased $K$ and decreased $L_{\infty}$ values (both sexes) with increasing temperatures in a subtropical Brazilian beach (Fora beach: $22^{\circ} 57^{\prime} \mathrm{S}, 43^{\circ} 10^{\prime} \mathrm{W}$ ), which is comparable to the results obtained here for the same species (Fig. 8). Therefore, this space-for-time substitution modeling approach (Fukami \& Wardle 2005, Blois et al. 2013, Lester et al. 2014) could be useful for predicting responses of sandy beach populations for which long-term records are scarce (Lima et al. 2000, Revell et al. 2011).

In summary, the long-term variations in abundance, population structure, and individual growth 
of E. brasiliensis were influenced by SST. Given the steady increase in SSTA in the study area (Ortega et al. 2012) and the tropical origin of the mole crab, the species is expected to expand its range poleward as a pioneer or colonizer ('leading edge' sensu Poloczanska et al. 2013) over time. This expansion could be more feasible during La Niña years, when the effect of the physical barrier given by the Rio de la Plata estuary is weakened and the incidence of the warm and salty waters driven by the tropical Brazil Current markedly increases (Ortega \& Martínez 2007). Potential increases in SST could increase fertility and reproductive periodicity of the mole crab on Uruguayan beaches at the southernmost end of its geographic distribution. We suggest considering biogeographic affinity and mode of development of sandy beach species to assess long term effects of climate variability. Finally, the space-for-time substitution has proven useful in understanding long-term responses of the mole crab population and is highlighted as a future research venue in addressing potential changes in population processes resulting from climate change in these data-poor ecosystems.

Acknowledgements. This paper is part of E.C.'s PhD thesis. We thank the 'Benthic Ecology Group' of UNDECIMAR for field and laboratory assistance. The financial support provided by CONICYT (FCE 4034), CSIC-Grupos (C633), Agencia Nacional de Investigación e Innovación (ANII), Programa de Desarrollo de las Ciencias Básicas (PEDECIBA), and The Pew Fellows Program in Marine Conservation, is gratefully acknowledged.

\section{LITERATURE CITED}

Angilletta MJ (2009) Thermal adaptation. Oxford University Press, Oxford

> Arntz WE, Brey T, Tarazona J, Robles A (1987) Changes in the structure of a shallow sandy-beach community in Peru during an El Niño event. S Afr J Mar Sci 5:645-658

Baethgen WE, Giménez A (2001) Applying seasonal climate forecasts and satellite information for improving decisions in the agricultural sector: the 1999-2000 drought in Uruguay. Open Meeting of the Human Dimensions of Global Environmental Change Research Community, Rio de Janeiro, 6-8 Oct 2001, p 1-17

> Barboza FR, Defeo O (2015) Global diversity patterns in sandy beach macrofauna: a biogeographic analysis. Sci Rep 5:14515

Bergamino L, Lercari D, Defeo O (2011) Food web structure of sandy beaches: temporal and spatial variation using stable isotope analysis. Estuar Coast Shelf Sci 91: 536-543

Bessa F, Gonc SC, Franco JN, André JN, Cunha PP, Marques JC (2014) Temporal changes in macrofauna as response indicator to potential human pressures on sandy beaches. Ecol Indic 41:49-57
Blois JL, Williams JW, Fitzpatrick MC, Jackson ST, Ferrier S (2013) Space can substitute for time in predicting climate-change effects on biodiversity. Proc Natl Acad Sci USA 110:9374-9379

- Brown CJ, Schoeman DS, Sydeman WJ, Brander K and others (2011) Quantitative approaches in climate change ecology. Glob Change Biol 17:3697-3713

Caddy J, Defeo O (2003) Enhancing or restoring the productivity of natural populations of shellfish and other marine invertebrate resources. FAO Fish Tech Pap 448. FAO, Rome

Celentano E (2014) Ecología poblacional del crustáceo Emerita brasiliensis (Decapoda, Hippidae), en la costa uruguaya: un análisis a múltiples escalas espaciales y temporales. $\mathrm{PhD}$ thesis, University of the Republic, Montevideo

Celentano E, Defeo O (2006) Habitat harshness and morphodynamics: life history traits of the mole crab Emerita brasiliensis in Uruguayan sandy beaches. Mar Biol 149: 1453-1461

Celentano E, Gutiérrez NL, Defeo O (2010) Effects of morphodynamic and estuarine gradients on the demography and distribution of a sandy beach mole crab: implications for source-sink habitat dynamics. Mar Ecol Prog Ser 398: 193-205

Cerrato RM (1990) Interpretable statistical tests for growth comparisons using parameters in the von Bertalanffy equation. Can J Fish Aquat Sci 47:1416-1426

Chambers LE, Altwegg R, Barbraud C, Barnard P and others (2013) Phenological changes in the southern hemisphere. PLoS One 8:e75514

Chen IC, Hill JK, Ohlemuller R, Roy DB, Thomas CD (2011) Rapid range shifts of species associated with high levels of climate warming. Science 333:1024-1026

Defeo O (1996) Experimental management of an exploited sandy beach bivalve population. Rev Chil Hist Nat 69: 605-614

Defeo O (2003) Marine invertebrate fisheries in sandy beaches: an overview. J Coast Res 35:56-65

> Defeo O, Cardoso RS (2002) Macroecology of population dynamics and life history traits of the mole crab Emerita brasiliensis in Atlantic sandy beaches of South America. Mar Ecol Prog Ser 239:169-179

> Defeo O, Cardoso R (2004) Latitudinal patterns in abundance and life-history traits of the mole crab Emerita brasiliensis on South American sandy beaches. Divers Distrib 10:89-98

> Defeo O, de Alava A (1995) Effects of human activities on long-term trends in sandy beach populations: the wedge clam Donax hanleyanus in Uruguay. Mar Ecol Prog Ser 123:73-82

> Defeo O, McLachlan A (2013) Global patterns in sandy beach macrofauna: species richness, abundance, biomass and body size. Geomorphology 199:106-114

Defeo O, McLachlan A, Schoeman DS, Schlacher $\mathrm{T}$ and others (2009) Threats to sandy beach ecosystems: a review. Estuar Coast Shelf Sci 81:1-12

Defeo O, Castrejón M, Ortega L, Kuhn AM, Gutiérrez NL, Castilla JC (2013) Impacts of climate variability on Latin American small-scale fisheries. Ecol Soc 18:30

> Diaz AF, Studzinski CD, Mechoso CR (1998) Relationships between precipitation anomalies in Uruguay and southern Brazil and sea surface temperature in the Pacific and Atlantic Oceans. J Clim 11:251-271

Dugan J, Hubbard DM, Wenner AM (1994) Geographic variation in life history of the sand crab, Emerita analoga 
(Stimpson) on the California coast: relationships to environmental variables. J Exp Mar Biol Ecol 181: 255-278

Dugan JE, Defeo O, Jaramillo E, Jones AR and others (2010) Ocean beaches under assault of climate change. Science 329:1146

Edeline E, Lacroix G, Delire C, Poulet N, Legendre S (2013) Ecological emergence of thermal clines in body size. Glob Change Biol 19:3062-3068

Fiori S, Vidal-Martínez VM, Simá-Álvarez R, RodríguezCanul R, Aguirre-Macedo ML, Defeo O (2004) Field and laboratory observations of the mass mortality of the yellow clam Mesodesma mactroides in South America: the case of Isla del Jabalí, Argentina. J Shellfish Res 23: 451-455

Fukami T, Wardle DA (2005) Long-term ecological dynamics: reciprocal insights from natural and anthropogenic gradients. Proc R Soc Lond B Biol Sci 272:2105-2115

Gallucci VF, Quinn TJ (1979) Reparametrizing fitting and testing a simple growth model. Trans Am Fish Soc 108: $14-25$

Gardner JL, Peters A, Kearney MR, Joseph L, Heinsohn R (2011) Declining body size: a third universal response to warming? Trends Ecol Evol 26:285-291

Gayanilo F, Pauly D (1997) FAO-ICLARM stock assessment tools. Reference Manual. FAO Computerized Information Series (Fisheries) No. 8. FAO, Rome

$>$ Gómez J, Defeo O (1999) Life history of the sandhopper Pseudorchestoidea brasiliensis (Amphipoda) in sandy beaches with contrasting morphodynamics. Mar Ecol Prog Ser 182:209-220

Goss-Custard JD, McGrorty S, Kirby R (1990) Inshore birds of the soft coasts and sea-level rise. In: Beukema JJ, Wolff WJ, Brouns JJWM (eds) Expected effects of climate change on marine coastal ecosystems. Kluwer Academic Publishers, Dordrecht, p 189-193

Grimm A (2011) Interannual climate variability in South America: impacts on seasonal precipitation, extreme events, and possible effects of climate change. Stochastic Environ Res Risk Assess 25:537-554

Haddon M (2001) Modelling and quantitative methods in fisheries. Chapman \& Hall/CRC, Boca Raton, FL

IPCC (Intergovernmental Panel on Climate Change) (2014) Climate change: impacts, adaptation, and vulnerability. In: Field CB, Barros VR, Dokken DJ, Mach KJ and others (eds) Contribution of Working Group II to the Fifth Assessment Report of the Intergovernmental Panel on Climate Change. Part A: global and sectoral aspects. Cambridge University Press, Cambridge, p 1-1132

IRI/LDEO (International Research Institute/Lamont-Doherty Earth Observatory) (2013) Climate data library. http:// iridl.ldeo.columbia.edu/maproom/Global/Ocean_Temp/ index.html

Kimura DK (1980) Likelihood methods for the von Bertalanffy growth curve. Fish Bull 77:765-775

> Lester RE, Close PG, Barton JL, Pope AJ, Brown SC (2014) Predicting the likely response of data-poor ecosystems to climate change using space-for-time substitution across domains. Glob Change Biol 20:3471-3481

- Lima M, Brazeiro A, Defeo O (2000) Population dynamics of the yellow clam Mesodesma mactroides: recruitment variability, density-dependence and stochastic processes. Mar Ecol Prog Ser 207:97-108

McLachlan A, Dorvlo A (2005) Global patterns in sandy beach macrobenthic communities. J Coast Res 21:
$674-681$

Niedzielski T (2014) El Niño/Southern Oscillation and selected environmental consequences. Adv Geophys 55: $77-122$

Odebrecht C, Rörig L, Garcia VT, Abreau PC (1995) Shellfish mortality and a red tide event in southern Brazil. In: Lassus P, Arzul G, Erard E, Gentien P, Marcaillou C (eds) Harmful marine algal blooms. Lavoisier Publishing, Paris, p 213-218

Odebrecht C, Du Preez DR, Abreu PC, Campbell EE (2014) Surf zone diatoms: a review of the drivers, patterns and role in sandy beaches food chains. Estuar Coast Shelf Sci 150:24-35

> Ortega L, Martínez A (2007) Multiannual and seasonal variability of water masses and fronts over the Uruguayan shelf. J Coast Res 23:618-629

Ortega L, Castilla JC, Espino M, Yamashiro C, Defeo O (2012) Effects of fishing, market price, and climate on two South American clam species. Mar Ecol Prog Ser 469:71-85

Ortega L, Celentano E, Finkl C, Defeo O (2013) Effects of climate variability on the morphodynamics of Uruguayan sandy beaches. J Coast Res 29:747-755

> Ortega L, Celentano E, Delgado E, Defeo O (2016) Climate change influences on abundance, individual size and body abnormalities in a sandy beach clam. Mar Ecol Prog Ser 545:203-213

> Ottersen G, Planque B, Belgrano A, Post E, Reid PC, Stenseth NC (2001) Ecological effects of the North Atlantic Oscillation. Oecologia 128:1-14

Parmesan C (2007) Influences of species, latitudes and methodologies on estimates of phenological response to global warming. Glob Change Biol 13:1860-1872

Parmesan C, Yohe G (2003) A globally coherent fingerprint of climate change impacts across natural systems. Nature 421:37-42

Pauly D, Munro JL (1984) Once more on the comparison of growth in fish and invertebrates. Fishbyte 2:21

Pethick J (1993) Shoreline adjustments and coastal management: physical and biological processes under accelerated sea-level rise. Geogr J 159:162-168

Pickett S (1989) Space-for-time substitution as an alternative to long-term studies. In: Likens GE (ed) Long-term studies in ecology: approaches and alternatives. Springer, New York, NY, p 110-135

Poloczanska ES, Hawkins SJ, Southward AJ, Burrows MT (2008) Modeling the response of populations of competing species to climate change. Ecology 89:3138-3149

Poloczanska ES, Brown CJ, Sydeman WJ, Kiessling W and others (2013) Global imprint of climate change on marine life. Nat Clim Change 3:919-925

Poloczanska ES, Hoegh-Guldberg O, Cheung E, Pörtner HO, Burrows M (2014) Cross-chapter box on observed global responses of marine biogeography, abundance, and phenology to climate change. In: Field CB, Barros VR, Dokken DJ, Mach KJ and others (eds) Climate change 2014: impacts, adaptation, and vulnerability. Part A: global and sectoral aspects. Contribution of Working Group II to the Fifth Assessment Report of the Intergovernmental Panel on Climate Change. Cambridge University Press, Cambridge, p 123-127

Revell DL, Dugan JE, Hubbard DM (2011) Physical and ecological responses of sandy beaches to the 1997-98 El Niño. J Coast Res 27:718-730

Reynolds RW, Rayner NA, Smith TM, Stokes DC, Wang W 
(2002) An improved in situ and satellite SST analysis for climate. J Clim 15:1609-1625

Riascos JM (2006) Effects of El Niño-Southern oscillation on the population dynamics of the tropical bivalve Donax dentifer from Málaga bay, Colombian Pacific. Mar Biol 148:1283-1293

Riascos JM, Carstensen D, Laudien J, Arntz WE, Oliva ME, Güntner A, Heilmayer O (2009) Thriving and declining: climate variability shaping life-history and population persistence of Mesodesma donacium in the Humboldt Upwelling System. Mar Ecol Prog Ser 385:151-163

Sagarin RD, Barry JP, Gilman SE, Baxter CH (1999) Climaterelated change in an intertidal community over short and long time scales. Ecol Monogr 69:465-490

Schoeman DS, Schlacher TA, Defeo O (2014) Climatechange impacts on sandy-beach biota: crossing a line in

Editorial responsibility: Romuald Lipcius,

Gloucester Point, Virginia, USA the sand. Glob Change Biol 20:2383-2392

Schwartz M (2013) Phenology: an integrative environmental science. Springer, Dordrecht

Sexton JP, McIntyre PJ, Angert AL, Rice KJ (2009) Evolution and ecology of species range limits. Annu Rev Ecol Evol Syst 40:415-436

Subramoniam T, Gunamalai V (2003) Breeding biology of the intertidal sand crab, Emerita (Decapoda: Anomura). Adv Mar Biol 46:91-182

Veloso V, Cardoso R (1999) Population biology of the mole crab Emerita brasiliensis (Decapoda: Hippidae) at Fora Beach, Brazil. J Crustac Biol 19:147-153

Yamanaka T, Raffaelli D, White P (2010) Physical determinants of intertidal communities on dissipative beaches: implications of sea-level rise. Estuar Coast Shelf Sci 88: $267-278$

Submitted: January 18, 2016; Accepted: May 10, 2016

Proofs received from author(s): June 6, 2016 